\title{
Impact of an Infrastructure Development Policy on Health, Poverty \& Crime Actions in Indonesia (Case Study in Majalengka District)
}

\author{
Entang Adhy Muhtar* and Budiman Rusli
}

\author{
Departement of Public Administration, Faculty of Social and Political Science, Universitas Padjadjaran, \\ Indonesia
}

\begin{abstract}
With the construction of toll roads, the welfare of the people in the area has also changed. Toll road infrastructure plays a very important role in supporting the economy, social, culture, unity, and dynamics of community life. Majalengka Regency is one of the areas affected by the construction of the Cipali Toll Road (Cikampek-Palimanan). The results showed that in 2014, the life expectancy at birth in Majalengka Regency was only 68.66 years, and in 2019 it had reached 69.97 years. 85.43 percent of households live in their own houses, the remaining 14.57 percent of households live in houses that are not their own. When viewed at a glance, the percentage of own homeownership status in the 2018-2019 period, it can be seen that the percentage of the population who live in their own homes has increased by around 7 percent. The poor population in Majalengka Regency in total showed a downward trend during the 2015-2019 period (a condition in March). In 2015, the number of poor people was 167.50 thousand people or 14.19 percent of the total population of Majalengka Regency. In the 2019 period, the population who became victims of crime continued to experience a decline by 0.72 points to 0.88 percent compared to 2018 which reached 1.60 .
\end{abstract}

Keywords: Policy, Infrastructure, Health, Poverty, Crime Actions, Majalengka.

\section{INTRODUCTION}

With the construction of toll roads, economic growth in the region has also changed. The construction of toll roads in China has succeeded in spurring its economy, leveling development, and also advancing its remote areas. This toll road can make China exploit the economic capacity of its region so that in the end it can sustain the country to become a world economic giant. Not only in China, but toll roads also have many positive impacts on big cities in Europe, because the existence of toll roads can unravel traffic congestion and also reduce social disparities (Sumaryoto, 2010).

Infrastructure development in West Java, especially toll roads is needed to reduce congestion on the Pantura Route and to increase the distribution of goods and services, especially in areas with high levels of development, also, the existence of toll roads it can make the region-the center of the economy. Toll road infrastructure plays a very important role in supporting the economy, social, culture, unity, and dynamics of community life in terms of interaction, as well as binding and connecting regions in West Java and Indonesia. Toll road infrastructure is also a facility that connects production sources, markets, and consumers.

Majalengka Regency is one of the areas affected by the construction of the Cipali Toll Road (CikampekPalimanan). There are at least 180,629 square meters

${ }^{*}$ Address correspondence to this author at the Departement of Public Administration, Faculty of Social and Political Science, Universitas Padjadjaran, Indonesia; Tel: (022) 2510276; Fax: (022) 2510276;

E-mail: entang.apunpad@gmail.com of land acquisition in five sub-districts in Majalengka Regency, namely in Sumber Jaya, Kertajati, Dawuan, Jatiwangi, and Ligung Districts. It is undeniable that the construction of the Cipali Toll Road will have an impact on the existing socio-economic conditions in the future on the areas around the toll road. One of them is Majalengka Regency, as one of the areas affected by development.

This development policy can have an impact on the social and economic conditions of the people who are the target of change, as well as those who are outside the target. The social impact is felt directly by residents whose land has been acquired and relocated as a result of toll road construction, namely, the fear of unfulfilled aspirations for their future welfare. On July 3 , 2016, there was a vertical conflict between the community and the government, there were still 50 residents from Jatiwangi and Sumberjaya Districts who rallied at the KM 166 Rest Area to demand proper compensation, they are not yet willing to accept compensation because the value offered by the government is too low. This shows that land acquisition carried out by the government at that time was deemed not fulfilling a sense of justice for the affected communities.

With various developments including toll roads, Majalengka Regency began to establish many factories from Karawang, Bekasi, Cikarang, and Bandung Raya that relocated their business to the Majalengka area. On average, the factories were built on land in the northern area, or adjacent to the Cipali Toll road. The construction of this factory is spread out from the 
District of Dawuan, Palasah, Kasokandel, Kadipaten, Ligung, and Sumberjaya. This can be seen based on the 2016 RTRW of Majalengka Regency, the northern area, namely the District of Kadipaten, Jatiwangi, and Sumberjaya, will be used as an industrial area, while in the southern area it will be used as an agro-industrial and water absorption area. The potential for growing investment in the industrial sector in Majalengka Regency is inseparable from the easy access to land transportation to accelerate the distribution of goods and people to industrial areas. However, industrial development is also expected not to take agricultural land that has been planned in the RTRW of Majalengka Regency, considering that most of the population's livelihood is as farmers.

Apart from the industrial sector, the development also has the potential to increase business in the property sector and small and medium enterprises. Investment and business in the property sector can increase along with the growth of the industrial sector because there will be an increase in the population around the industrial area. Also, small and medium enterprises of the local population can also increase. Local entrepreneurs can take advantage of the rest areas that have been built at km 166 and km 170, where local entrepreneurs can market local products in the form of opening culinary shops, restaurants, and even working in the area.

According to information from the Bappeda of Majalengka Regency, currently, the Majalengka Regency Government is developing agro-tourism in the Gedong Gincu mango plantation area in Sidamukti Village, Majalengka District, and a durian garden in Sinapeul, Sindangwangi District. The construction of the Cipali Toll Road has the potential to increase the income of people working in the agro-industry sector. With the opening of the toll road, the sale and purchase of products that were only marketed within the city will have the opportunity to be sold outside the city.

By looking at the impact of the construction of the Cipali Toll Road, researchers are interested in uncovering how the impact of infrastructure development policies (Tol Cipali) on health, poverty \& crime in Indonesia (case study in Majalengka Regency).

\section{LITERATURE REVIEW}

\section{Impact of Infra Structure Development Policy}

Policy impact analysis is included in the objectives and scope of evaluation studies, as expressed by
Weiss (1972), Wibawa (1994) and Anggara (2014), Dunn (1998), stating that the purpose of evaluation analysis is more to measure the effects and impacts of a program/policy. in society. Measuring the effect of a policy on people's lives by comparing conditions before and after the policy was issued.

Soemarwoto in Giroth (2004: 12) says that an impact is a change that occurs as a result of an activity. Furthermore, Soemarwoto explained that "these activities can be natural, in the form of chemical, physical or biological, can also be carried out by humans in the form of environmental impact analysis, development, and planning. The impacts can be biophysical, social, economic and cultural ".

Meanwhile, according to Anggara (2014: 280) impact is a change in physical or social conditions as a result of policy output. The consequences of a program intervention on the target group and the extent to which these effects can lead to new behavior patterns in the target group (impact) The consequences of a program intervention on the target group, both those that are expected and those that are not capable of causing behavior new to the target group (effects).

Dye, Anderson, Lester, and Stewart in Winarno (2007) and Anggara (2014) stated that the impact of a public policy has several dimensions, and all of them must be taken into account in discussing evaluation. There are five dimensions of a policy impact according to Dye in Winarno (2007: 232-235) and Anggara (2014: 281), namely:

The impact of policy on public matters and the impact of policy on the people involved. Thus, the objectives in public policy that are expected to be influenced by the policy must be limited, and the expected impact of the policy must be determined from the beginning of public policymaking. Policies may have an impact on circumstances or groups beyond the goals or objectives of the policy than previously predicted by policy-making actors. Policies are likely to have an impact on current and future conditions which will affect both target groups and beyond.

Impact of toll road infrastructure development policies, about the process it will not only have an impact on changes in natural conditions but will also have consequences on the socio-economic conditions of the surrounding community. According to Salim (1979) which in Trilaksono (2010: 12) the development process creates mobility so that one community group 
is related, sometimes even colliding with other groups, colliding with one another's social values. Big projects can create shocks and imbalances in the social environment. Both developments with large leaps and large project developments affect the social environment.

Furthermore, Salim (1979) in Trilaksono (2010: 9) argues that the essence of development also aims to generate diversity and diversification in socialeconomic activities such as the development of the agricultural, industrial, mining, service sectors, and others. However, it does not forget about environmental balance.

There are several problems that can be identified:

1. The development of toll road infrastructure cannot be enjoyed by all stakeholders forever, but there is often a wider socio-economic gap.

2. The infrastructure development policy, on the one hand, creates diversity in the community's economic diversification, but on the other hand, it also creates environmental degradation that is not conducive.

3. The development process creates mobility so that one group of people relates, and sometimes even collides, with other groups, which can cause shocks and imbalances in the social environment.

4. Policy strategy for infrastructure development is seen more from the physical environmental impact, whereas the socio-economic environmental impacts are far more complex and long-term.

\section{METHOD RESEARCH}

Development and social problems, a research approach is needed that can help researchers to understand the phenomena related to these problems. Creswell (2010: 1 ) describes a qualitative approach as follows: "This study is defined as inquiry of understanding a social a human problem, based on building a complex, holistic picture, formed with words reporting detailed views of informants, and conducted in a natural setting".

By looking at the phenomenon under study regarding the impact of infrastructure development policies that are unique and complex, this research uses qualitative methods. Qualitative methods aim to understand and interpret the meaning of a phenomenon that occurs, to be analyzed, and attempt to explain the phenomenon with descriptions. by which the author is given an assessment. Thus, in the end, the researcher can give meaning to the results of the research in-depth.

\section{Data, Data Collection Techniques, and Data Sources}

To analyze the impact of infrastructure development policies, the authors use primary data, secondary data related to these problems. The data collection techniques used in this research are library research and field studies. Literature study conducted by researchers is by examining, reading, searching, and comparing various theoretical literature sources such as books, journals, relevant studies. Field studies (field research) carried out by observation, is a technique of collecting data and information by making direct observations of the object under study, in this observation the researcher is involved or directly participates in the activities of the subject being observed, and interviews are carried out, which is a technique of collecting information data with conducting in-depth direct questions and answers (in-depthinterview) by asking for direct explanations from the parties involved and competent. The information used as a source of information with the author's consideration to determine the informants in this study are: Authority/authority possessed by the informant, considered has a lot of information and is appropriate, Has a relationship, both individually and in agencies. Info man includes the Head of Bappeda, the Head of Bina Marga da Cipta Karya, the Social Service, the Investment Service, and Integrated Services, the Tourism Office, PBS Majalengka Regency, the Transportation Service, the Head of Sub-District, Heads of Village and community leaders as well as business actors and other related parties. The analysis was carried out using the triangulation method, namely by checking and cross-checking the information received to see the similarities and alignments, as well as differences.

The triangulation results are then compiled into a descriptive summary, by looking at the similarities and differences in opinions and views in the community, complemented by problem analysis, needs assessment, and potential analysis. After the description of the analysis is compiled, the conclusion is drawn. 


\section{RESULT AND DISCUSSION}

Majalengka Regency is one of the districts formed during the Dutch East Indies Government. Majalengka Regency has economic value for the Dutch East Indies Government, at least from the commodity trading of coffee, sugar cane, and tea. Based on the Besluit dated January 5, 1819 Number 23, the CommissionerGeneral of the Dutch East Indies established the Maja Regency which included the former Rajagaluh and Talaga Regencies. Maja Regency covers three districts, namely Talaga, Sindangkasih, and Rajagaluh which covers an area of 625 palms and borders Sumedang (west), Cirebon and Kuningan (east), Indramayu (north), and Galuh and Sukapura (south) (Behoort by Misjive van den Resident van Cheribon van den 3 November 1837 No. 2006, AD Cirebon 64.9). In the 1830s, Maja Regency was divided into six districts, namely Maja, Sindangkasih, Rajagaluh, Talaga, Palimanan, and Kadongdong. In 1840, by the Governor-General D. J. de Eerens No. 2 dated February 11, 1840, the Dutch East Indies Government changed the name of Maja Regency to Majalengka Regency with the center of government domiciled in Sindangkasih. In addition to changing the name of Maja Regency to Majalengka Regency, the Dutch East Indies Government also changed the center of the Majalengka Regency government which was previously named Sindangkasih to Majalengka.

Changes in the administrative area of the regency government changed again in 1862. Based on the Besluit of the Governor-General of the Dutch East Indies Number 4 dated May 24, 1862, Palimanan District was removed from the Majalengka administrative area and entered into the Cirebon Regency area. The reason for this transfer was that the Palimanan District was closer to the power center of Cirebon Regency than to the district power center (Staatsblad van Nederlandsch-Indië, No.54 of 1862).

The area of Majalengka Regency is $1,204.24 \mathrm{~km} 2$ $(120,424$ hectares), or only about $2.71 \%$ of the area of West Java Province (which is approximately $44,357.00$ $\mathrm{Km} 2$ ) with an altitude between $19-857 \mathrm{~m}$ above sea level. The following are the administrative boundaries of Majalengka Regency:

- South side, bordering Ciamis Regency and Tasikmalaya Regency

- West side, bordering Sumedang Regency

- $\quad$ North side, bordering Indramayu Regency
- $\quad$ East side, bordering Cirebon Regency and Kuningan Regency

Administratively at the end of 2017, Majalengka Regency is divided into 26 sub-districts consisting of 13 sub-districts and 330 villages. The lowest number of governance in Majalengka Regency based on local environmental units consists of 2,129 Rukun Warga / Rukun Keluarga and 6,417 Rukun Tetangga. Following are the administrative areas of the sub-districts in Majalengka, which are presented in table form along with the number of Kelurahan / Desa, RW, and RT in them.

Based on the results of population projections for 2010-2020, the total population of Majalengka Regency in 2017 was $1,193,725$ people. Compared to the projected population in 2016 of $1,188,004$ people, the population of Majalengka Regency has grown by 0.48 percent. When viewed from the composition of the population of Majalengka Regency based on gender, the female population is 597,095 or $50.02 \%$ more than the male population, amounting to 596,630 men or $49.98 \%$, with a sex ratio of 99.92 . The average population density of Majalengka Regency in 2017 was 991 people / km2, the highest population density was in Jatiwangi District with a density of 2,105 people / km2 and the lowest density was in Kertajati District with a density of 308 people / km2.

The Cikopo-Palimanan (Cipali) toll road is a toll road that stretches 116 kilometers and is said to be the longest toll road in Indonesia. The toll road connects the Cikopo area, Purwakarta with the Palimanan area, Cirebon. And passing through five (5) districts/cities in West Java province, namely, Purwakarta, Subang, Majalengka, Indramayu, and also Cirebon. This toll road was completed on June 13, 2015. Cipali Toll Road is part of the Trans-Java toll road, which connects Merak, Banten to Banyuwangi, East Java (Cirebon, n.d.). One of the functions of toll roads is to connect production centers and global markets, therefore to facilitate road business activities, toll roads are a good alternative to accelerate the flow of goods in and out (Sumaryoto, 2010). This will help increase the economic activity of people in rural areas, which are in the average middle to lower class so that the gap between big cities and rural areas can be minimized. This toll road itself can support economic development in big and metropolitan cities. This is due to the ease of mobilization between regions via toll roads, and it can cut travel time faster. 


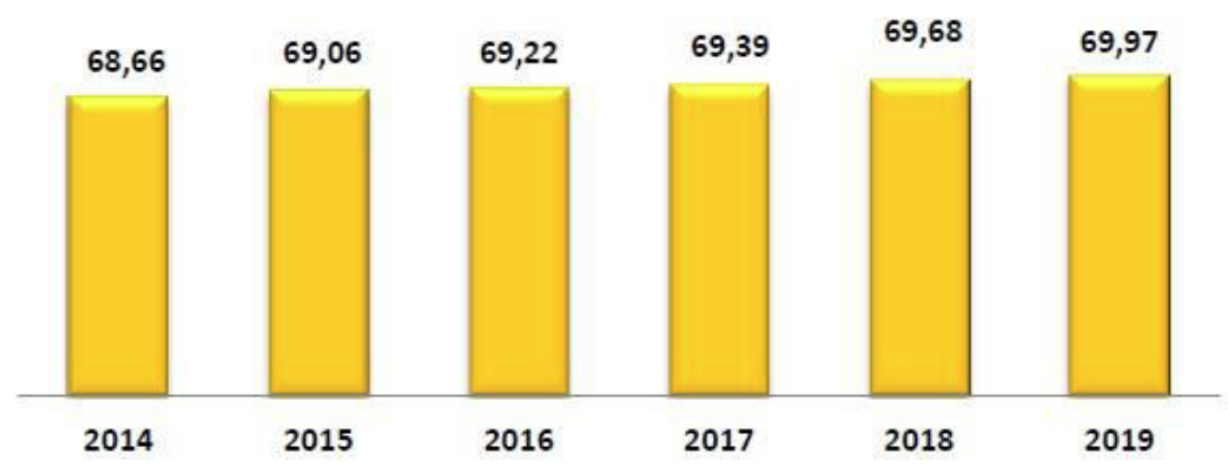

Figure 1: Life Expectancy at Birth, Majalengka Regency (Years), 2014-2019.

Source: IPM Majalengka, 2014 - 2019.

The degree of public health (public health level) is one of the most important indicators in describing the level of community welfare and the quality of human development in an area. The goal of human development in the health sector is to achieve the ability to live healthily for every population, so that the responsibility for the creation of an optimal health degree rests with the whole community, government, and private sector together.

The better the public health conditions in an area will encourage the acceleration of the process and dynamics of economic development, particularly in increasing work productivity. The government, both central and regional, has carried out various policy program interventions in the health sector to improve the degree of public health, such as by increasing the percentage of people who have access to the first health facilities through the provision of free BPJS contributions for the less fortunate. Build public health facilities, such as hospitals, puskesmas, posyandu, and other health facilities. Increase the number of health workers. Also, the government also makes it easy for people to enjoy health services.

The health dimension can be seen from the Life Expectancy Rate at birth which represents the dimensions of longevity and healthy life. During the period 2014 to 2019, Majalengka Regency has succeeded in increasing the Life Expectancy at Birth by 2.65 years. In 2014, the life expectancy at birth in
Majalengka Regency was only 68.66 years, and in 2019 it has reached 69.97 years.

The increasing life expectancy indicates that the people of Majalengka Regency are experiencing a longer age from year to year. The increase in life expectancy is very much influenced by many factors, such as better and more accessible health services for all groups of society, health behavior by the wider community, and better socio-economic conditions of the community accompanied by support for improved environmental health.

Talking about the level of people's welfare and the improvement of people's living standards in terms of housing, of course, the first and foremost thing that must be discussed is the status of homeownership itself. Household economic conditions greatly affect residential ownership. Residential ownership status covered here is a house owned by yourself, contract, rent, free rent, official house, house owned by parents/relatives, or another ownership status. A household that occupies a house that belongs to itself can be said to have been able to meet the need for secure and permanent housing in the long term.

To encourage and facilitate the fulfillment of the needs of habitable housing ownership for people, especially low-income people, the government has consistently provided various stimuli in the housing sector. The fiscal stimulus is in the form of Interest

Table 1: Percentage of Households by Residential Ownership Status in Majalengka Regency, 2017 - 2019

\begin{tabular}{|c|c|c|c|c|}
\hline Indicator & Unit & $\mathbf{2 0 1 7}$ & $\mathbf{2 0 1 8}$ & $\mathbf{2 0 1 9}$ \\
\hline $\mathbf{( 1 )}$ & $\mathbf{( 2 )}$ & $\mathbf{( 3 )}$ & $\mathbf{( 4 )}$ & $\mathbf{( 5 )}$ \\
\hline \hline One's own & $\%$ & 82,93 & 78,17 & 85,43 \\
\hline Home Office / Others & $\%$ & 17,07 & 21,83 & 14,75 \\
\hline
\end{tabular}

Source: Susenas March 2017 - 2019. 
Selisish Subsidy (SSB) and Advance Assistance Subsidy (SBUM) for people who buy houses with a credit scheme through a Home Ownership Credit (KPR).

The results of the 2019 Susenas in Table 1 show that households who live in their own homes are 85.43 percent, the remaining 14.57 percent of households live in houses that do not belong to them. When viewed at a glance, the percentage of own homeownership status in the 2018-2019 period, it can be seen that the percentage of the population who live in their own homes has increased by around 7 percent.

The proliferation of housing complex developments in Majalengka Regency in the last 3 years shows the high public interest in owning their own house and can indicate an increase in the standard of living and welfare of the community.

Poverty is a complex problem that is influenced by various interrelated factors, including income level, health, education, access to goods and services, location, geography, gender, and environmental conditions. The definition of poverty formulated by the BPS is an economic inability to meet basic food and non-food needs as measured in terms of expenditure.

The causes of poverty are divided into 2 kinds. The first is cultural poverty, which is poverty caused by the presence of customary or cultural factors in a certain area that shackles a certain person or group of people so that they remain attached to poverty. Poverty like this can be eliminated or can be reduced by ignoring the factors that prevent him from making changes towards a better level of life. Second is structural poverty, namely poverty that occurs as a result of the powerlessness of a person or a certain group of people against an unfair social system or order, therefore they are in a very weak bargaining position and do not have access to develop and free themselves from the traps of poverty or in other words "a person or a group of people becomes poor because they are poor".

Conceptually, poverty can be distinguished according to relative poverty and absolute poverty, where the difference lies in the standard of assessment. The relative poverty assessment standard is a standard of living that is determined and subjectively determined by the local community and is local and those who fall below the assessment standard are categorized as relatively poor. The absolute poverty assessment standard is the minimum standard of living needed to meet the basic needs needed, both food and non-food. The minimum standard of living to meet basic needs is known as the poverty line.

The poor population in Majalengka Regency in total showed a downward trend during the 2015-2019 period (a condition in March). In 2015, the number of poor people was 167.50 thousand people or 14.19 percent of the total population of Majalengka Regency.

The government continues to reduce the poverty rate, and in March 2019 the number of poor people has decreased to 121.06 thousand people or 10.06 percent of the total population in Majalengka Regency. This figure is still slightly above the national poverty percentage in 2019, which is 9.41 percent. Local governments need to spend extra manpower to formulate targeted and targeted policy interventions so that they can effectively reduce the percentage of poor people significantly.

The level of security in an area can be used as a measure of community welfare. The high percentage of crime victims indicates that the level of community

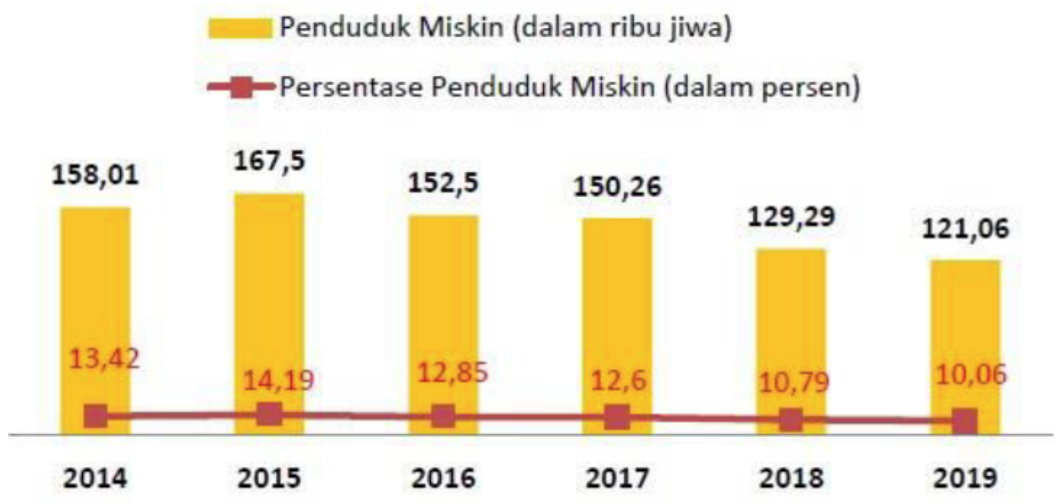

Figure 2: Number and Percentage of Poor Population in Majalengka Regency, 2014 - 2019 (March, thousand inhabitants). Sumber: Statistik Daerah Provinsi Jawa Barat, 2014 - 2019. 
Table 2: Percentage of Population who have become Victims of Crime Since Last Year in Majalengka Regency, 2017 2019

\begin{tabular}{|c|c|c|c|}
\hline Gender & $\mathbf{2 0 1 7}$ & $\mathbf{2 0 1 8}$ & $\mathbf{2 0 1 9}$ \\
\hline $\mathbf{( 1 )}$ & $\mathbf{( 2 )}$ & $\mathbf{( 3 )}$ & 1,94 \\
\hline Male & 2,15 & 1,26 & 0,21 \\
\hline Female & 1,66 & 1,60 & 0,88 \\
\hline
\end{tabular}

Source: Susenas Maret, 2017 - 2019.

welfare in the area is still lacking, thus encouraging perpetrators to commit crimes. The crime victims covered in the Susenas March 2017-2019 are all forms of crime victims except for murder crimes.

In the 2019 period, the population who became victims of crime continued to experience a decline by 0.72 points to 0.88 percent compared to 2018 which reached 1.60. The decrease in the percentage of victims of crime occurred in men and women. The percentage decline in males reached 0.73 percentage points, while the decrease in victims of crime for females reached 0.71 percentage points.

\section{CONCLUSION}

In general, it shows that the Cipali toll road has an impact on public health, poverty, and crime in Majalengka Regency. Life expectancy at birth in Majalengka Regency in 2019 has reached 69.97 years. The poor population in Majalengka Regency in total shows a downward trend during the 2015-2019 period. In the 2019 period, the population who became victims of crime continued to experience a decline by 0.72 points to 0.88 percent compared to 2018 which reached 1.60 .

\section{REFERENCES}

Ayu Andani, I. G., Geurs, K., \& Puello, L. L. P. (2019). Effects of toll road construction on local road projects in Indonesia. Journal of Transport and Land Use, 12(1), 179-199. https://doi.org/10.5198/jtlu.2019.1258

Aziz Hartanto, A., \& Pradoto, W. (2014). Pengaruh Pembangunan Jalan Tol Terhadap Perubahan Pola dan Struktur Ruang Kawasan Sidomulyo, Unggaran Timur. Jurnal Teknik PWK, 3.

Badan Pusat Statistik Kabupaten Majalengka: Kabupaten Majalengka dalam Angka 2019.

BPS. (n.d.-c). PDRB Kabupaten Majalengka. Retrieved from https://majalengkakab.bps.go.id/statictable/2017/07/05/90/pd rb-kabupaten-majalengka-atas-dasar-harga-konstan-2010menurut-lapangan-usaha-juta-rupiah-2010-2016.html

Cirebon, R. (n.d.). Tol Cipali Perkuat Ekonomi Cirebon. Https://Radarcirebon.Com/Tol-Cipali-Perkuat-EkonomiCirebon.Html.

Deputi Bidang Sarana dan Prasarana Kementerian PPN/ Bappenas RI: Konektivitas Infrastruktur Wilayah dan Antar Wilayah 2014.

Eko, T., \& Rahayu, S. (2012). Perubahan Penggunaan Lahan dan Kesesuaiannya terhadap RDTR di Wilayah Peri-Urban Studi Kasus : Kecamatan Mlati. 8(4), 330-340. https://doi.org/10.14710/pwk.v8i4.6487

Ma'ruf, A., \& Wihastuti, L. (2008). Pertumbuhan Ekonomi Indonesia: Determinan dan Prospeknya. Jurnal Ekonomi Dan Studi Pembangunan, 9, 44-55.

Republik Indonesia, Peraturan Pemerintah No. 15 Tahun 2005 Tentang Jalan Tol

Sumaryoto. (2010). Dampak Keberadaan Jalan Tol Terhadap Kondisi Fisik, Sosial, dan Ekonomi Lingkungannya. Journal of Rural and Development, 1(2), 161-168.

\section{https://doi.org/10.6000/1929-4409.2021.10.66}

(C) 2021 Muhtar and Rusli; Licensee Lifescience Global.

This is an open access article licensed under the terms of the Creative Commons Attribution Non-Commercial License (http://creativecommons.org/licenses/by-nc/3.0/) which permits unrestricted, non-commercial use, distribution and reproduction in any medium, provided the work is properly cited. 